\title{
IN VITRO ANTIBACTERIAL EFFECT OF BREADFRUIT LEAF EXTRACT AGAINST STREPTOCOCCUS SANGUINIS ATCC 10556 BIOFILM
}

\author{
VAZA NADIA, SRI UTAMI, RATNA FARIDA* \\ Department of Oral Biology, Faculty of Dentistry, University of Indonesia, Jakarta, Indonesia. Email: friedakuayu@yahoo.co.id
}

Received: 12 October 2018, Revised and Accepted: 22 February 2019

ABSTRACT

Objective: Evidence indicates that breadfruit leaf extract may have antibacterial properties. In terms of bacterial plaque, Streptococcus sanguinis is known as an early agent of its formation. The purpose of this study was to analyze the antibacterial effects of breadfruit leaf extract on the growth of S. sanguinis.

Methods: S. sanguinis ATCC 10556 was cultured in 96-well plates and was incubated at $37^{\circ} \mathrm{C}$ for $20 \mathrm{~h}$ (the accumulation phase) or $24 \mathrm{~h}$ (the maturation phase). Then, breadfruit leaf extract was added at concentrations of 5, 10, 20, 40, 80, and 100\%. The viability of S. sanguinis was evaluated using the 3-(4,5-dimethylthiazol-2-yl)-2,5-diphenyltetrazolium bromide assay at a wavelength of $490 \mathrm{~nm}$.

Results: Our results demonstrated that the viability of $S$. sanguinis, after exposure to the breadfruit leaf extract at all concentrations, during the accumulation and maturation phases was lower than the control group $(\mathrm{p}<0.05)$. In addition, the viability of $S$. sanguinis after exposure to the breadfruit leaf extract at concentrations of 20,80 , and $100 \%$ during the accumulation phase was lower than that observed during the maturation phase.

Conclusion: Collectively, our novel findings should provide insight into the potential of breadfruit leaf extract to positively affect oral and dental health.

Keywords: Breadfruit leaf extract, 3-(4,5-Dimethylthiazol-2-yl)-2,5-diphenyltetrazolium bromide assay, Streptococcus sanguinis, Viability.

(C) 2019 The Authors. Published by Innovare Academic Sciences Pvt Ltd. This is an open access article under the CC BY license (http://creativecommons. org/licenses/by/4. 0/) DOI: http://dx.doi.org/10.22159/ijap.2019.v11s1.AR200

\section{INTRODUCTION}

Breadfruit (Artocarpus altilis) is typically used as an intercropping plant in the yard. The breadfruit plant originated from New Guinea and was later developed in Malaysia and Indonesia [1]. Indeed, breadfruit trees are widely encountered in Indonesia, particularly in hot areas and valleys. In addition to the fact that it is delicious, the leaves of the breadfruit tree are used to treat many types of diseases, including diabetes mellitus and hypertension [2].

Streptococcus sanguinis is a Gram-positive, facultative anaerobic bacteria. S. sanguinis directly binds to pellicle on the tooth surface utilizing various mechanisms, one of which involves binding to saliva proteins that are proline rich. Once bound, S. sanguinis facilitates other bacteria to colonize on the tooth surface to form biofilms [3]. Then, Streptococcus mutans, Streptococcus sobrinus, and Lactobacillus, all of which are cariogenic bacteria, are progressively incorporated into the biofilm. The cariogenic bacteria are acidogenic that capable of producing acid from carbohydrates consumed by the host [4]. This acid produced by the bacteria causes a reduction in the $\mathrm{pH}$ of plaque, which causes dental caries due to demineralization [5]. Thus, S. sanguinis bacteria indirectly contribute to the occurrence of dental caries by forming early colonies of biofilm.

The formation of biofilm formation is divided into three phases: The adhesion phase $(0-4 \mathrm{~h})$, the accumulation phase $(4-20 \mathrm{~h})$, and the maturation phase (after $20 \mathrm{~h}$ ) [6]. In the adhesion phase, bacteria such as Streptococci (61-78\%) and Actinomyces (4-30\%) are found predominantly attached to the pellicle. Types of Streptococci include S. sanguinis, Streptococcus mitis, and Streptococcus oralis [7]. In the accumulation phase, due to accumulation and rapid growth, the amount of bacteria in the biofilm increases exponentially [8]. After $20 \mathrm{~h}$, the maturation phase in which bacterial growth begins to slow down or stop due to limited nutrients occurs [7].
Phytochemical tests of breadfruit leaf extract (A. altilis), using the maceration method with $70 \%$ ethanol, have indicated that the extract contains active compounds including secondary metabolites that function as antibacterial agents. These include flavonoids, polyphenols, quinones, steroids, saponin, monoterpene, and sesquiterpene [9]. Antibacterial compounds can kill bacteria by suppressing its growth or its ability to reproduce. An ideal antimicrobial agent has selective toxicity, indicating that it is harmful to the parasite but not to the host $[10,11]$. The results of a recent study have indicated that antibacterial agents kill bacteria effectively at the time the bacteria are growing (i.e., during the accumulation phase) [12].

Based on the active compounds that may act as antibacterial agents present in the leaves of the breadfruit, as well as evidence, suggesting that $S$. sanguinis is an early colonizer that plays a role in the early formation of plaque, the aim of this study was to examine the antibacterial effect of breadfruit extract against the viability of $S$. sanguinis during both the accumulation $(20 \mathrm{~h})$ and the maturation (24 h) phases. We expect that our findings will aid in the development and utilization of the breadfruit plant as a traditional medicinal plant that may improve oral and dental health.

\section{METHODS}

This study was based on a laboratory experimental design. The research was conducted in the Laboratory of Oral Biology, FKG UI. The bacterial sample used was S. sanguinis ATCC 10556.

\section{Preparation of $\boldsymbol{S}$. sanguinis solution}

The main solution was prepared by taking several bacterial colonies from the culture on the BHI and inserting them into a $10 \mathrm{~mL} \mathrm{BHI}$ broth tube. Then, the main solution was inserted into the anaerobic jar and was filled with $95 \% \mathrm{NO}_{2}$ and $5 \% \mathrm{CO}_{2}$. Next, the solution was incubated at $37^{\circ} \mathrm{C}$ for $24 \mathrm{~h}$. 
Determination of the concentration range of the breadfruit leaf extract

Before making the various concentrations, the breadfruit leaf extract was filtered using a Minisart with a diameter of $0.2 \mathrm{~mm}$. The breadfruit leaf extract was made according to the desired concentrations of 5, 10, $20,40,80$, and $100 \%$

\section{Biofilm model preparation}

For the preparation of the biofilm, $100 \mu \mathrm{L}$ of artificial saliva was inserted into every 96 well-plate and was incubated at $37^{\circ} \mathrm{C}$ for $90 \mathrm{~min}$. The saliva that was not attached to the well was removed and was rinsed with $100 \mu \mathrm{L}$ phosphate-buffered saline (PBS). Furthermore, $100 \mu \mathrm{L}$ of $S$. sanguinis bacteria at $10^{6} \mathrm{CFU} / \mathrm{mL}$ standardized suspension was used to expose each well and incubated for $20 \mathrm{~h}$ and $24 \mathrm{~h}$ at $37^{\circ} \mathrm{C}$. Wells with formed biofilms were rinsed with $100 \mu \mathrm{L}$ PBS solution.

\section{Exposure to the breadfruit leaf extract}

In each well plate that had formed a biofilm, we added $100 \mu \mathrm{L}$ of extract at various concentrations. For the positive control, each well was exposed to $100 \mu \mathrm{L}$ chlorhexidine (0.1\%) (Chl 0.1\%). For the negative control, the biofilm model was exposed to BHI without an antibacterial agent. Then, the well plate was inserted into an anaerobic jar containing $95 \% \mathrm{NO}_{2}$ and $5 \% \mathrm{CO}_{2}$ mixed gas and incubated for $2 \mathrm{~h}$ at $37^{\circ} \mathrm{C}$. Finally, the 3-(4,5-dimethylthiazol-2-yl)-2,5-diphenyltetrazolium bromide (MTT) test was performed. $50 \mu \mathrm{L}$ of MTT solution was added to each $96-$ well plate and was incubated for $3 \mathrm{~h}$ at $37^{\circ} \mathrm{C}$. Then, $100 \mu \mathrm{L}$ of acidified isopropanol was added to each well and placed on the shaker for $1 \mathrm{~h}$. The optical density (OD) values were read on a microplate reader with a wavelength of $490 \mathrm{~nm}$.

The viability of $S$. sanguinis was calculated using the formula:

$$
\text { cell viability }(\%)=\frac{\text { Absorbance value of treatment group }}{\text { Absorbance value of controlgroup }} \times 100 \%
$$

\section{Data analysis}

One-way analysis of variance (ANOVA) was used to analyze the viability data for each treatment group of $S$. sanguinis.

\section{RESULTS}

In this study, we investigated the antibacterial effect of breadfruit extract against the viability of $S$. sanguinis using the MTT test. The viability was determined by the value of the OD, which was read with a wavelength of $490 \mathrm{~nm}$. The results of the Kolmogorov-Smirnov normality test showed that the data had a normal distribution $(p>0.05)$. The data were analyzed by one-way ANOVA.

Fig. 1 shows the viability of $S$. sanguinis control group as $100 \%$, with a mean value of OD $1.094 \pm 0.053$. Chl $0.1 \%$ was used as the positive control, which resulted in $S$. sanguinis viability of $14 \%$ (OD $0.157 \pm 0.02$ ). In the groups exposed to breadfruit leaf extract at different concentrations, S. sanguinis viability was $86 \%$ (5\% concentration; OD $0.945 \pm 0.164$ ), $66 \%$ ( $10 \%$ concentration; OD $0.718 \pm 0.083$ ), $42 \%$ (20\% concentration; OD $0.454 \pm 0.036), 40 \%$ ( $40 \%$ concentration; OD $0.437 \pm 0.053), 38 \%(80 \%$ concentration; OD $0.431 \pm 0.048$ ), and $36 \%$ (100\% concentration; OD $0.398 \pm 0.053)$. The statistical results revealed that all the treatment groups were significantly different compared with the control group $(\mathrm{p}<0.05)$.

Fig. 2 shows the viability of S. sanguinis in the control group of $100 \%$, with a mean value of OD $0.898 \pm 0.096$. Exposure to Chl $0.1 \%$ resulted in $S$ sanguinis viability of $23 \%$ (OD $0.21 \pm 0.046$ ). In the treatment groups exposed to the breadfruit leaf extract at different concentrations, $S$. sanguinis viability was 75\% (5\% concentration; OD $0.674 \pm 0.082$ ), 54\% (10\% concentration; OD $0.489 \pm 0.029$ ), $47 \%$ (20\% concentration; OD $0.422 \pm 0.062$ ), $38 \%$ ( $40 \%$ concentration; OD $0.340 \pm 0.027$ ), $50 \%(80 \%$ concentration; OD $0.437 \pm 0.045)$, and $56 \%$ ( $100 \%$ concentration; OD $0.498 \pm 0.029$ ). Our statistical results revealed that all the treatment groups were significantly different compared with the control group $(\mathrm{p}<0.05)$.

Fig. 3 shows a significant decrease in the viability of S. sanguinis biofilm. The viability of $S$. sanguinis after exposure to Chl $0.1 \%$ as the positive control at the $20 \mathrm{~h}$ phase was lower than that at the $24 \mathrm{~h}$ phase. This was observed also in the groups exposed to the breadfruit leaf extract at 20,80 , and $100 \%$, and there was a significant decrease in the viability of $S$. sanguinis at the $20 \mathrm{~h}$ phase compared with the $24 \mathrm{~h}$ phase $(\mathrm{p}<0.05)$. In addition, viability was different in the groups exposed to the breadfruit leaf extract at 5,10 , and $40 \%$ at the $20 \mathrm{~h}$ phase, which showed a

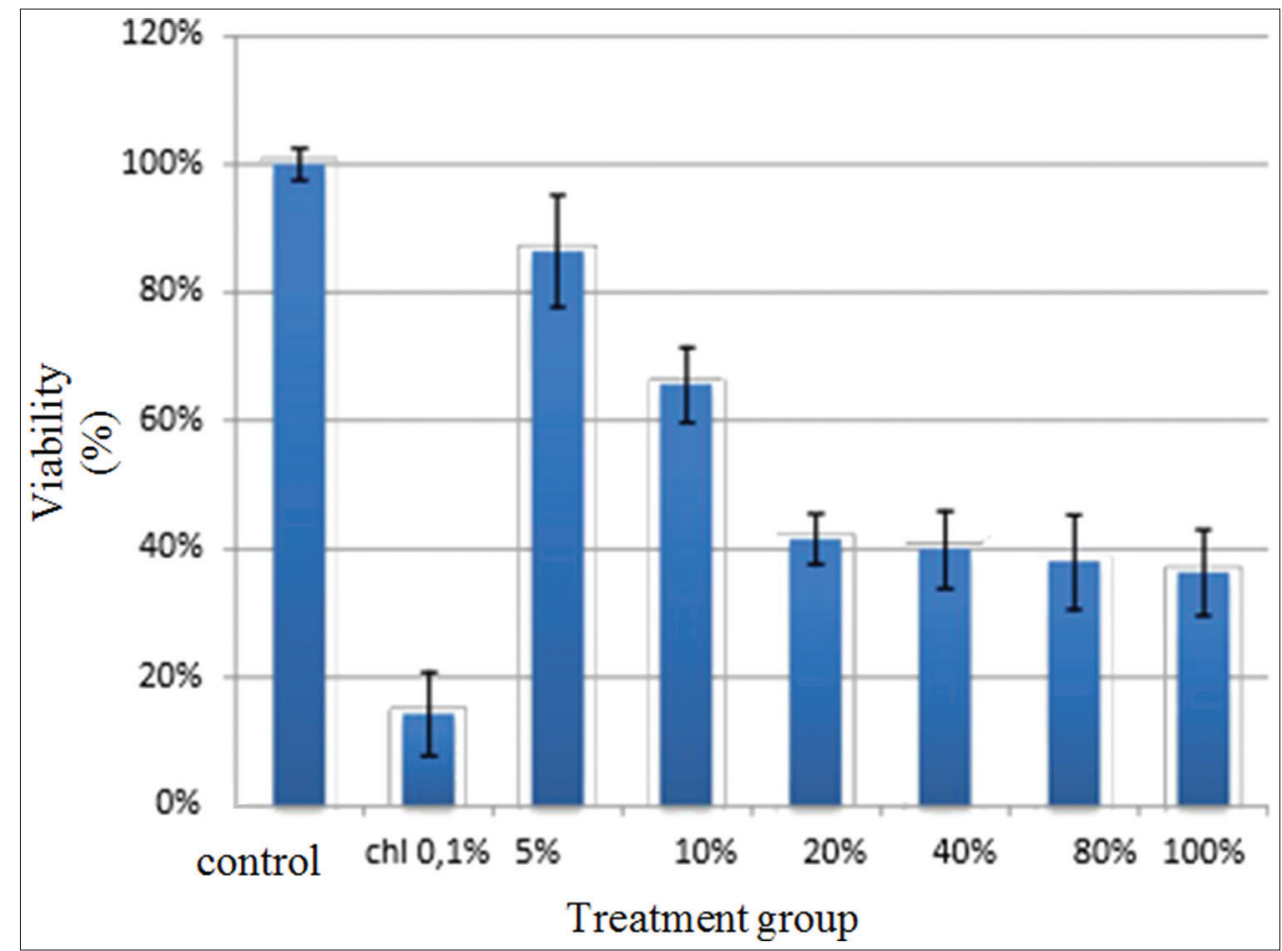

Fig. 1: Streptococcus sanguinis viability after exposure to the breadfruit leaf extract during the accumulation phase (20 h) 


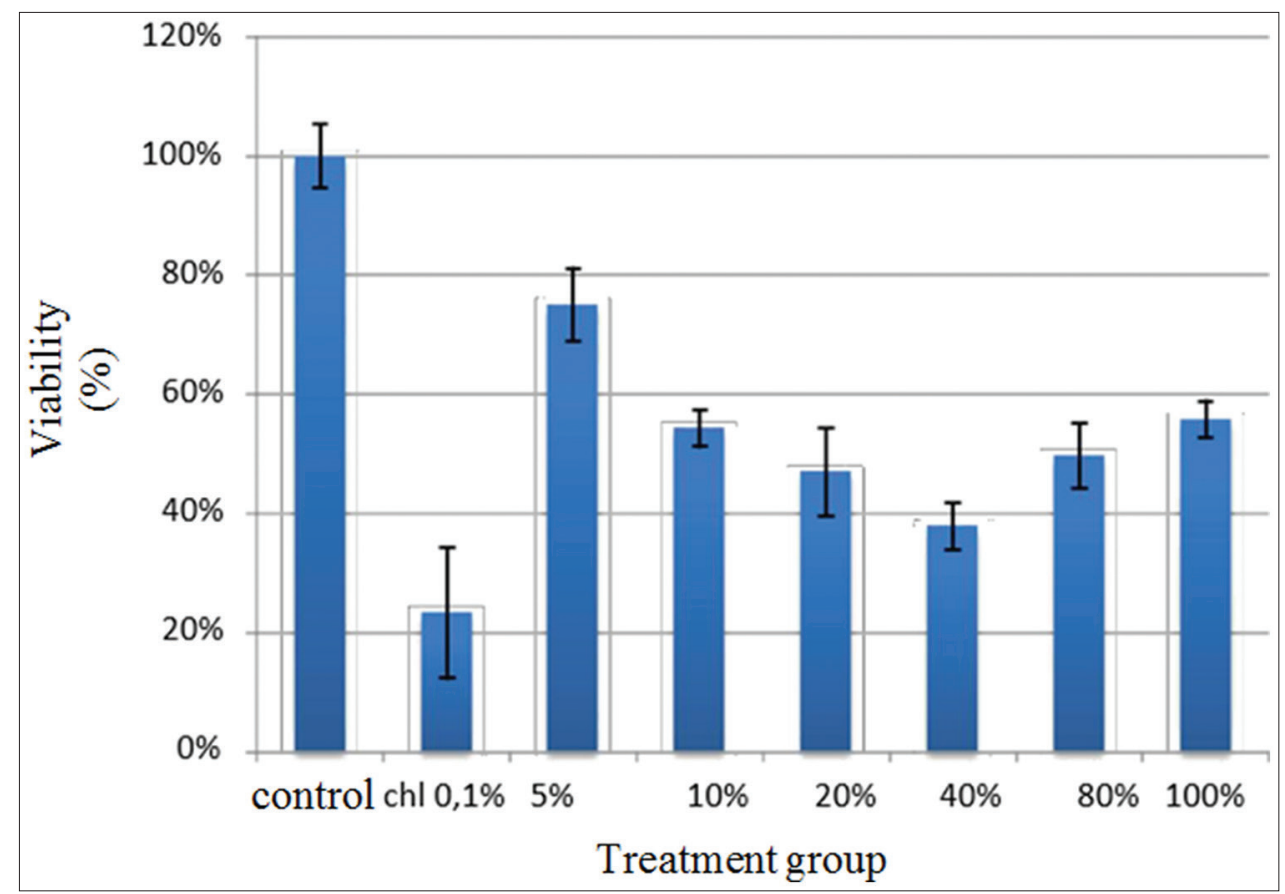

Fig. 2: Streptococcus sanguinis viability after exposure to the breadfruit leaf extract during the maturation phase $(24 \mathrm{~h})$

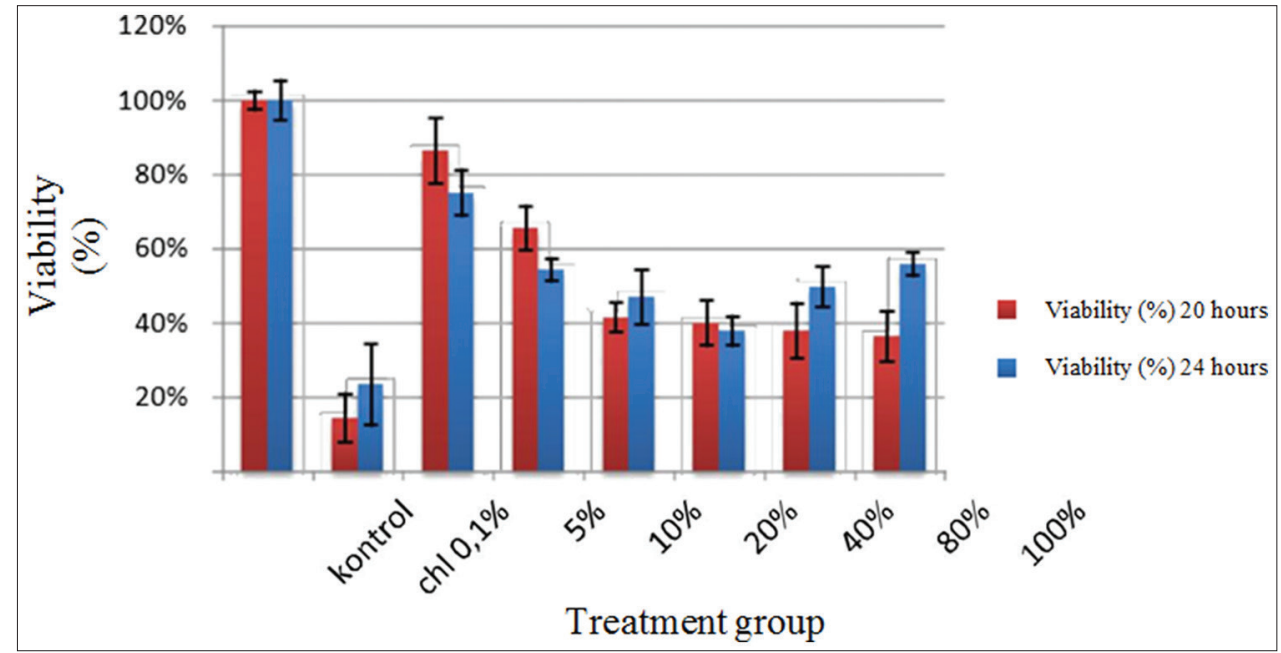

Fig. 3: Comparison of Streptococcus sanguinis biofilm viability after exposure to the breadfruit leaf extract for $20 \mathrm{~h}$ and $24 \mathrm{~h}$

significant increase in the viability of $S$. sanguinis compared with the 24 h phase $(\mathrm{p}<0.05)$.

\section{DISCUSSION}

Our results showed that the breadfruit leaf extract at concentrations of $5,10,20,40,80$, and $100 \%$ in the accumulation phase $(20 \mathrm{~h})$ and maturation phase $(24 \mathrm{~h})$ can decrease the viability of $S$. sanguinis compared with the control group. This decrease in the viability of $S$. sanguinis after exposure to the breadfruit leaf extract was suspected because the breadfruit leaf extract has been reported to have antibacterial properties due to the phenolic content consisting of tannins, saponins, and flavonoids. Indeed, tannin is believed to interfere with bacterial cell permeability, resulting in the inhibition of bacterial growth [13]. Similarly, saponins have antibacterial activity by disrupting cell permeability by inhibiting ionic membranes. Flavonoids are phenolic compounds that act as disinfectants and that work by denaturing proteins, which cause bacterial cell metabolism to stop resulting in cell death. Flavonoids are also bacteriostatic and serve to inhibit bacterial cell wall synthesis [14].
Our results showed that the breadfruit extract at a low concentration of 5\% was able to decrease the viability of S. sanguinis at the $20 \mathrm{~h}$ phase (Fig. 1). This is in accordance with other researches that have tested the breadfruit leaf extract against the Gram-positive bacteria Bacillus subtilis. The results of this previous study showed that the higher the concentration of the breadfruit leaf extract, the greater the inhibition, with a concentration of $5 \%$ being able to inhibit the growth of Gram-positive bacteria [15]. Our results are also in accordance with other studies using the MTT method to test the viability of $S$. sanguinis with a temulawak ethanol extract. The reported results showed a decrease in the viability of $S$. sanguinis with increasing concentrations of extract in the accumulation phase $(20 \mathrm{~h})$ [16].

Fig. 2 shows a decrease in the viability of $S$. sanguinis, along with increasing concentrations of the breadfruit leaf extract, from $5 \%$ to $40 \%$, in the maturation phase $(24 \mathrm{~h})$. However, at concentrations of $80 \%$ and $100 \%$, there was an increase in viability again. This may be because, during the maturation phase, the biofilm that has been formed can increase resistance to antibacterial agents. Indeed, evidence suggests that the thicker the biofilm, the more difficult it is for antibacterial 
agents to penetrate the biofilm [17]. During the maturation phase, the best optimum dose to decrease the viability of $S$. sanguinis appears to be $40 \%$ concentration of breadfruit leaf extract. It appears that at higher concentrations of breadfruit leaf extract, the viability decreases. However, after reaching an optimum point, the effectiveness of the breadfruit leaf extract decreases as a result of the increased viability of $S$. sanguinis [18]. While the previous study that examined the temulawak ethanol extract on the viability of $S$. sanguinis initially reported a decreased viability with a concentration of $5 \%$, viability then increased again at a concentration of $15 \%$, with a subsequent decrease again at a concentration of $25 \%$. The cause of this is not known; however, the authors suspected that the temulawak ethanol extract has different effects on the viability of $S$ sanguinis depending on the dosage of the extract used [16]

In Fig. 3, the exposure to the breadfruit leaf extract at 20, 80, and $100 \%$ showed that the viability of $S$. sanguinis at $20 \mathrm{~h}$ was lower than that at $24 \mathrm{~h}$. At the $24 \mathrm{~h}$ phase with the concentrations of 20,80 , and $100 \%$, $S$. sanguinis bacteria appeared to be resistant to the breadfruit leaf extract. It is possible that in the accumulation phase $(20 \mathrm{~h})$, bacterial growth is still active and facilitates antibacterial substances to work optimally. In contrast, during the maturation phase, the biofilm formed is thicker than in the accumulation phase; thus, antibacterial substances may have greater difficulty penetrating into biofilms $[8,17]$.

\section{CONCLUSION}

Breadfruit leaf extract at concentrations of 5, 10, 20, 40, 80, and 100\% decreases the viability of $S$. sanguinis biofilms in the accumulation phase $(20 \mathrm{~h})$ and maturation phase $(24 \mathrm{~h})$. However, the viability of $S$. sanguinis biofilms after exposure to the breadfruit leaf extract at 20, 80 , and $100 \%$ in the accumulation phase $(20 \mathrm{~h})$ was lower than that in the maturation phase $(24 \mathrm{~h})$.

\section{CONFLICTS OF INTEREST}

There are no conflicts of interest to declare.

\section{REFERENCES}

1. Cancer Treatment with Breadfruit Leaves; 2012. Available from: http:// www.mataharinews.com/kesehatan/obat-penyakit/1743-mengobati- kanker-dengan-daun-sukun.html

2. Litbang Deptan. National Workshop on Breadfruit Development. Available from: http://www.pustaka.litbang.deptan.go.id/publikasi/ wr31103.pdf.

3. Xu P, Alves JM, Kitten T, Brown A, Chen Z, Ozaki LS, et al. Genome of the opportunistic pathogen Streptococcus sanguinis. J Bacteriol 2007; 189:3166-75

4. Mount G, Hume WR. Dental Caries. Preservation and Restoration of Tooth Structure. $2^{\text {nd }}$ ed. Queens Land: Knowledge Books and Software; 2005. p. 25-21

5. Walsh LJ. Dental plaque fermentation and its role in caries risk assessment. Int Dent SA 2006;8:34-40.

6. Kolenbrander PE, Andersen RN, Blehert DS, Egland PG, Foster JS, Palmer RJ Jr., et al. Communication among oral bacteria. Microbiol Mol Biol Rev 2002;66:486-505.

7. Costerton JW, Lappin-Scott HM. Dental plaque. Microb Biofilms 1995;8:881-90.

8. Bowden GH, Li YH. Nutritional influences on biofilm development. Adv Dent Res 1997;11:81-99.

9. Abdassah M, Sumiwi SA, Hendrayana J. Formulation of breadfruit leaf extract (Artocarpus altilis (Parkins.) Fosberg) with base gel as antiinflammatory. J Farmasi Indones 2009;4:199-209.

10. Ganiswarna SG. Pharmacology and Therapy. $4^{\text {th }}$ ed. Jakarta: Gaya Baru; 2005. p. 571-3

11. Jawets E, Melnick JL, Adelberg EA. Medical Microbiology. $19^{\text {th }}$ ed. USA: Lange Medical Book; 1991. p. 149-52.

12. Lewis K. Riddle of biofilm resistance. Antimicrob Agents Chemother 2001;45:999-1007.

13. Doss A, Mubarack M, Dhanabalan R. Antibacterial activity of tannins from the leaves of Solanum trilobatum Linn. Indian J Sci Technol 2009;2:41-3.

14. Cushnie TP, Lamb AJ. Antimicrobial activity of flavonoids. Int $\mathrm{J}$ Antimicrob Agents 2005;26:343-56.

15. Sulistiyaningsih, Rostinawati T, Permana C. Antimicrobial activity of ethanol extract of breadfruit leaves against bacteria and fungi. Farmaka 2009; 7:1-13.

16. Nina C. The Effect of Temulawak Ethanol Extract on Streptococcus sanguinis Viability Based on MTT Test (in vitro). [Dissertation]. Jakarta: Fakultas Kedokteran Gigi Universitas Indonesia; 2011.

17. Mah TF, O'Toole GA. Mechanisms of biofilm resistance to antimicrobial agents. Trends Microbiol 2001;9:34-9.

18. Boyd R, Marr J. Medical Microbiology. $20^{\text {th }}$ ed. London: Prentice Hall; 1995. p. 218 